\title{
To the study of the lichen genus Usnea (Parmeliaceae) in Kunashir Island (Sakhalin Region, Russia)
}

\author{
L. V. Gagarina ${ }^{1}$, A. K. Ezhkin ${ }^{2}$ \\ ${ }^{1}$ Komarov Botanical Institute of the Russian Academy of Sciences, St. Petersburg, Russia \\ ${ }^{2}$ Institute of Marine Geology and Geophysics of the Far Eastern Branch of the Russian Academy of \\ Sciences, Yuzhno-Sakhalinsk, Russia \\ Corresponding author: L. V. Gagarina, gagarinalv@binran.ru
}

\begin{abstract}
Nine species from the genus Usnea were found in the Kunashir Island. Six species are new for the Kunashir Island. These are U. cornuta, U. glabrata, U. fragilescens, U. lapponica, U. pangiana, U. subfloridana. In total, six secondary medullary substances detected by HPTLC were found in the species of Usnea from Kunashir. Four new chemotypes are described. The paper provides a key for identification of Usnea species in the Kunashir Island, list of specimens examined, lists of chemotypes detected by authors and known from literature.
\end{abstract}

Keywords: chemistry, distribution, key, lichen substances, Kuril Islands.

\section{К изучению лишайников рода Usnea (Parmeliaceae) на острове Кунашир (Сахалинская область, Россия)}

\author{
Л. В. Гагарина ${ }^{1}$, А. К. Ежкин ${ }^{2}$ \\ ${ }^{1}$ Ботанический институт им. В. Л. Комарова РАН, Санкт-Петербург, Россия \\ ${ }^{2}$ Институт морской геологии и геофизики ДВО РАН, Южно-Сахалинск, Россия \\ Автор для переписки: Л. В. Гагарина, gagarinalv@binran.ru
}

Резюме. Девять видов рода Usnea выявлено на о. Кунашир. Шесть видов впервые обнаружены на Кунашире: U. cornuta, U. glabrata, U. fragilescens, U. lapponica, U. pangiana, U. subfloridana. Всего в талломах лишайников выявлено 6 лишайниковых веществ, идентифицировано 4 новых хемотипа. Приведен ключ для определения видов рода Usnea Кунашира, список изученных образцов, данные о выявленных и известных хемотипах.

Ключевые слова: ключ, лишайниковые вещества, распространение, химия, Курильские острова.

Kunashir is the southernmost island of the Kuril Islands, a volcanic archipelago in the Sea of Okhotsk in the northwest of the Pacific Ocean. The Kunashir Island with an area of 1490 square kilometers is currently administrated by the Sakhalin Region. The climate is temperate of monsoon type with heavy precipitation especially in autumn to $1400 \mathrm{~mm}$ and maximum temperatures in August to $18^{\circ} \mathrm{C}$ in average. Kunashir is included in the Sakhalin-Hokkaido province of the East Asian floristic region (Takhtadzhyan, 1978). Major part of Kunashir territory is covered by coniferous forests mostly formed by Abies sachalinensis (F. Schmidt) Mast., Picea jezoensis (Siebold et Zucc.) Carrière, and P. glehnii (F. Schmidt) Mast. A southern part of the is- 
land is covered by broad-leaved forests mostly formed by Quercus crispula Blume and Ulmus laciniata (Trautv.) Mayr.

The lichens of Kunashir are still poorly studied. A few areas of the island has been investigated and only particular groups of lichens has been previously revised (Insarov, Pchelkin, 1988; Titov, 1991; Bredkina et al., 1992; Dombrovskaya, 1996; Tchabanenko, 1999; Joneson et al., 2004; Makryi et al., 2010; Ezhkin, Kordyukov, 2016). To date, approximately 300 lichen species are known from the literature, therefore new and noteworthy records are highly expected for this territory.

The genus Usnea Dill. ex Adans. (Parmeliaceae, Ascomycota) consists of 355 widely distributed species (Wijayawardene et al., 2020). Of these, 40 species are known from Russia (Golubkova, 1996; Spisok..., 2010; Kharpukhaeva, 2011). The genus Usnea contains fruticose lichens with a central axis consisting of a cartilaginous stand of longitudinal hyphae. Thallus attached by a holdfast, pale greenish or yellow green, occasionally reddish brown or blackening. Branches cylindrical, fusiform, tapering or irregular, with or without papillae, fibrils, soralia, pseudocyphellae. Apothecia rare. Cortex composed of radially or irregularly oriented hyphae. Medulla lax, dense or compact, sometimes pink pigmented. Photobiont trebouxioid. Cortex contains usnic acid, chemistry of medulla is highly variable (Halonen et al., 1998; Articus, 2004; Randlane et al., 2009; Clerc, 2011). The delimitation of Usnea has been discussed by numerous authors (e. g., Ohmura, 2001, 2002, 2012; Articus, 2004; Divakar et al., 2017; Ohmura, Kashiwadani, 2018) and the concept of the genus has been changed over time.

Prior our study, only three Usnea species were known from Kunashir Island: U. diffracta, U. longissima, and U. rubicunda (Bredkina et al., 1992). The aim of our study is a revision of lichens of the genus Usnea of Kunashir.

\section{Material and methods}

Material from expeditions in Kunashir Island collected by Alexander Ezhkin in 2013-2017 (Fig. 1) was studied. Lichen identification was carried out by Ludmila Gagarina. The voucher specimens are kept in herbarium of the Institute of Marine Geology and Geophysics FEB RAS (SAK) and in herbarium of the laboratory lichenology and bryology of Komarov Botanical Institute (LE). The morphology and anatomy were studied using a light microscope and a dissecting microscope. HPTLC was performed according to the standard procedure (Culberson, Ammann, 1979; Kranner et al., 2002) using solvent systems A and B by Ludmila Gagarina in the laboratory of lichenology and bryology of Komarov Botanical Institute.

\section{Results}

Nine species of the genus Usnea were found in Kunashir Island: U. cornuta, U. diffracta, U. glabrata, U. fragilescens, U. lapponica, U. longissima, U. pangiana, U. rubicunda, U. subfloridana. Of these, U. cornuta, U. glabrata, U. fragilescens, U. lapponica, $U$. pangiana, U. subfloridana are new for Kunashir Island. 


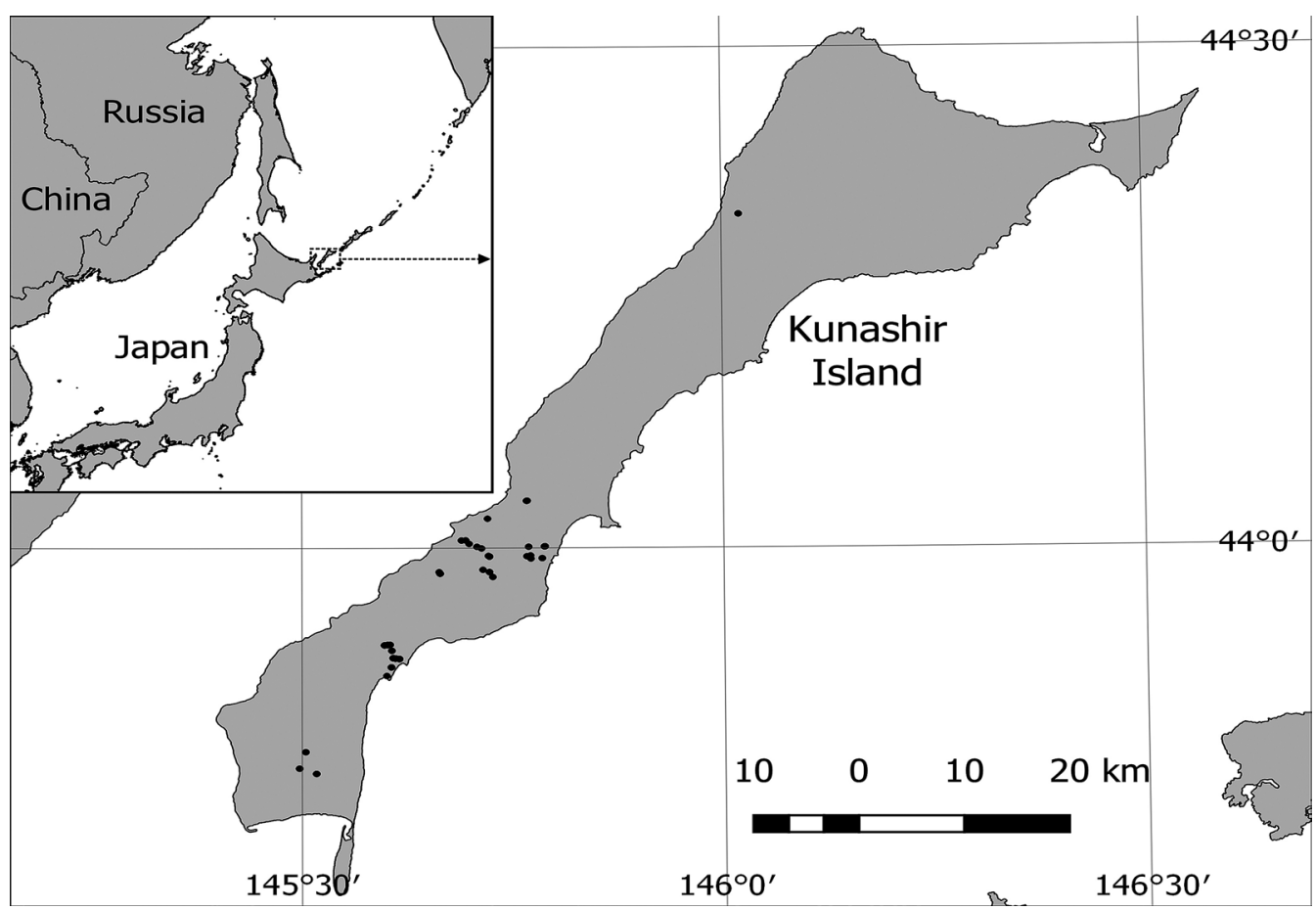

Fig. 1. Collecting localities in Kunashir Island.

\section{Key to the species of Usnea in Kunashir Island}

1. Thallus pendulous, decorticated on the main branch, with numerous perpendicular fibrils U. longissima

- Thallus shrubby or subpendent, corticated .2

2. Branches with annular-pseudocyphellae (bamboo-like appearance), thallus isotomicdichotomously branched U. diffracta

- Branches without annular-pseudocyphellae, thallus anisotomic- or isotomic-dichotomously branched

3. Red pigment present in cortex

U. rubicunda

- Red pigment absent in cortex or present in medulla.

4. Secondary branches distinctly and more or less consistently constricted at the point of attachment

- Secondary branches not constricted at the point of attachment

5. Soralia present, these generally bearing soredia, isidia always absent U. glabrata

- Soralia absent or, if present, then at least in part bearing isidia

6. Thallus clearly shrubby, upper branches unevenly anisotomically branched, readily divisible into main stems and secondary branches, isidiate soralia are concentrated at branch tips, becoming confluent. U. cornuta 
- Thallus shrubby to subpendent, upper branches evenly isotomical branched, generally not readily divisible into main stems and secondary branches, isidiate soralia are scattered over branches, remain discrete U. fragilecsens

7. Thallus shrubby, with distinctive concave large soralia, becoming expanded, isidia often absent (sometimes tuberculate soralia may contain spinules), medulla thick and loose U. lapponica

- Thallus erect to subpendent, with punctiform or convex soralia, smaller than the branch diam., isidia rare or abundant

8. Thallus with jet black base, with small to enlarged soralia, which often contain abundant isidia. U. subfloridana

- Thallus with concolor to dark brown base, with punctiform soralia, rarely with isidia.U. pangiana

\section{The species}

Usnea cornuta Körb. Ten chemotypes have been reported in literature for $U$. cornuta: 1) usnic, salazinic, and protocetraric ( \pm ) acids in Europe (Clerc, 1987; James et al., 2009; Randlane et al., 2009) and Japan (Asahina, 1956; Ohmura, 2001); 2) usnic, stictic, norstictic, and salazinic ( \pm ) acids in Europe (Clerc, 1987; James et al., 2009; Randlane et al., 2009); 3) usnic, lobaric, and norstictic acids in North America (Clerc, 2007); 4) usnic and norstictic acids in North America (Clerc, 2007); 5) usnic and protocetraric acids in North America (Clerc, 2007) and Japan (Asahina, 1956; Ohmura, 2001); 6) usnic, norstictic, protocertaric, and salazinic acids in Russian Far East (Ohmura et al., 2017) and Taiwan (Ohmura, 2012); 7) usnic, norstictic, menegazziaic, stictic, and constictic acids in Russian Far East (Ohmura et al., 2017); 8) usnic acid in North America (Clerc, 2007) and Russian Far East (Ohmura et al., 2017); 9) usnic and salazinic acids in Japan (Asahina, 1956). Stevens (1999) reported occurrence of diffractaic, fumarprotocetraric, and galbinic acids in Australia.

One chemical race was found - usnic and salazinic acids.

Specimens examined: Mendeleev Volcano, NW slope, 4359'29.5"N, 14543'20.0"E, $328 \mathrm{~m}$ a. s. 1., spruce-fir forest, bark of Abies sachalinensis, 28 VII 2013, Ezhkin, SAK 324; vicinity of Mendeleev Volcano, 4359'33.1"N, 14546'15.4"E, $161 \mathrm{~m}$ a. s. 1., spruce-fir forest, bark of A. sachalinensis, $21 \mathrm{VI}$ 2014, Ezhkin, SAK 337; ibidem, $44^{\circ} 00^{\prime} 05.5^{\prime \prime N}$, $145^{\circ} 47^{\prime} 14.6 " \mathrm{E}, 37 \mathrm{~m}$ a. s. 1., spruce-fir forest, bark of A. sachalinensis, 17 VI 2014, Ezhkin, SAK 349.

U. diffracta Vain. Six chemotypes have been reported for U. diffracta: 1) usnic, diffractaic, barbatic, baeomycesic, squamatic, and bourgeanic $( \pm)$ acids, atranorin $( \pm$ ) in Japan (Ohmura, 2001), Taiwan (Ohmura, 2012), South Korea (Jayalal et al., 2013), and Russian Far East (Ohmura et al., 2017); 2) usnic and diffractaic acids in Japan (Asahina, 1956); 3) usnic, diffractaic, barbatic, 4-O-demethylbarbatic, baeomycesic, squamatic, and salazinic acids in Japan (Ohmura, 2001); 4) usnic, barbatic, 4-O-demethylbarbatic, baeomycesic, squamatic, and salazinic acids in Japan (Ohmura 2001); 5) usnic and bourgeanic acids in Japan (Ohmura, 2001); 6) usnic, barbatic, baeomycesic, and squamatic acids in South Korea (Jayalal et al., 2013).

One chemical race was found in Kunashir - usnic and diffractaic acids.

Specimens examined: Mendeleev Volcano surroundings, Mt. Mechnikov, $43^{\circ} 58^{\prime} 42.0^{\prime \prime} \mathrm{N}$, $145^{\circ} 42^{\prime} 52.1$ "E, 340 m a. s. 1., dark coniferous forest, bark of Picea glehnii, 6 VIII 2013, Ezhkin, SAK 
1257; ibidem, $44^{\circ} 00^{\prime} 15.3^{\prime \prime N}, 145^{\circ} 41^{\prime} 53.5^{\prime \prime E}, 201 \mathrm{~m}$ a. s. 1., mixed forest, bark of Quersus crispula, $1 \mathrm{VIII}$ 2013, Ezhkin, SAK 1256; Mendeleev Volcano, NW slope, 4359'58.8"N, 14542'46.5"E, 343 m a. s. 1., dark coniferous forest, bark of Picea glehnii, 5 VIII 2015, Ezhkin, SAK 1255; Dubovoye village surroundings, $43^{\circ} 47^{\prime} 47.0^{\prime \prime} \mathrm{N}, 145^{\circ} 30^{\prime} 15.3^{\prime \prime} \mathrm{E}, 107 \mathrm{~m}$ a. s. l., dark coniferous forest, bark of Quersus crispula, 23 VIII 2017, Ezhkin, SAK 1258; Belkina River valley, 4354'10.9"N, 14535'51.1"E, 56 m a. s. 1., old-growth mixed coniferous-broadleaved forest, bark of Ulmus laciniata, 23 VI 2014, Ezhkin, SAK

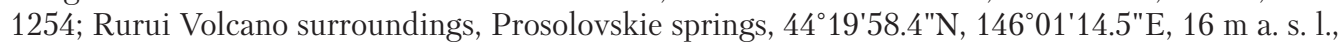
old-growth mixed coniferous-broadleaved forest, bark of Sorbus commixta Hedl., 19 VI 2014, Ezhkin, SAK 1259; Tretyakova village surroundings, 4353'23.5"N, $145^{\circ} 36^{\prime} 37.7 " \mathrm{E}, 37 \mathrm{~m}$ a. s. 1., old-growth mixed coniferous-broadleaved forest, bark of Ulmus laciniata, 23 VI 2014, Ezhkin, SAK 1253.

Usnea fragilescens Hav. ex Lynge. Seven chemotypes have been reported in literature for $U$. fragilescens: 1$)$ usnic, norstictic, salazinic, and protocetraric ( \pm ) acids in Russian Far East (Ohmura et al., 2017); 2) usnic, norstictic, stictic ( \pm ), menegazziaic $( \pm)$, and fatty $( \pm$ ) acids in Russian Far East (Ohmura et al., 2017), Japan, and Taiwan (Ohmura, 2001); 3) usnic, stictic, cryptostictic $( \pm)$, and menegazziaic $( \pm)$ acids in Japan and Taiwan (Ohmura, 2001); 4) usnic, salazinic, stictic acid complex ( \pm ), atranorin ( \pm ) in Japan and Taiwan (Ohmura, 2001); 5) usnic, psoromic, and 2-O-demethylpsoromic acids in Japan and Taiwan (Ohmura, 2001); 6) usnic acid in Japan and Taiwan (Ohmura, 2001); 7) usnic, stictic acid complex in Europe (Randlane et al., 2009); 8) usnic, salazinic acids in North America (Clerc, 2007); 9) usnic, psoromic acids in North America (Clerc, 2007).

Two chemotypes were found - usnic, salazinic acids; usnic acid.

Specimens examined: Belkina River valley, 4354'12.1"N, 14536'4.1"E, 77 m a. s. 1., mixed coniferous-deciduous forest, bark of Betula ermanii Cham., 23 VI 2014, Ezhkin, SAK 341, 343 (SAK 341 - without medulla substances, SAK 343 - salazinic acid); Mendeleev Volcano surroundings, Mechnikov Mt., 4358'33.7"N, 14543'19.8"E, 469 m a. s. 1., spruce-fir forest, bark of Picea jezoensis, 6 VIII 2013, Ezhkin, SAK 351.

U. glabrata (Ach.) Vain. Six chemotypes have been reported in literature for U. glabrata: 1) usnic, protocetraric, and fumarprotocetraric acids in Europe and North America (Randlane et al., 2009); 2) usnic, salazinic, and norstictic acids in Fennoscandia (Halonen et al., 1999); 3) usnic acid in Europe and North America (Clerc, 1987; Myllys, 1994; Brodo et al., 2001); 4) usnic, salazinic acids in Japan (Asahina, 1956) and Russian Far East (Ohmura et al., 2017); 5) usnic, barbatic, 4-O-demethylbarbatic (trace), norstictic $( \pm)$, and protocetraric $( \pm)$ acids in Russian Far East (Ohmura et al., 2017); 6) usnic acid in Europe (Brodo et al., 2001).

Four chemotypes were found - usnic, protocetraric, salazinic, thamnolic acids; usnic, salazinic acids; usnic, protocetraric, salazinic acids; usnic acid. Chemotype with thamnolic acid was not previously known for this species. Chemotype with usnic, protocetraric, and salazinic acids together is new for Kunashir.

Specimens examined: Belkina River valley, 4353'24.8"N, $145^{\circ} 36^{\prime} 28.3^{\prime \prime E}, 66 \mathrm{~m}$ a. s. 1., mixed coniferous-deciduous forest, bark of Abies sachalinensis, 23 VI 2014, Ezhkin, SAK 363; ibidem, $43^{\circ} 53^{\prime} 21.9^{\prime \prime} \mathrm{N}, 145^{\circ} 36^{\prime} 54.7^{\prime \prime E}, 30 \mathrm{~m}$ a. s. 1., mixed coniferous-deciduous forest, bark of Betula ermanii,

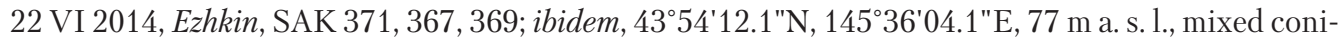
ferous-deciduous forest, bark of B. ermanii, 23 VI 2014, Ezhkin, SAK 344; vicinity of Lagunnoe Lake, 
$44^{\circ} 02^{\prime} 49.7^{\prime \prime N}, 145^{\circ} 45^{\prime} 59.1^{\prime \prime E}, 65 \mathrm{~m}$ a. s. 1., mixed coniferous-deciduous forest, bark of Ulmus laciniata, 17 VIII 2013, Ezhkin, SAK 332; vicinity of Mendeleev Volcano, 4400'05.9"N, 145 47'17.6"E, 29 m a. s. 1., spruce-fir forest, bark of Abies sachalinensis, 17 VI 2014, Ezhkin, SAK 352.

U. lapponica Vain. Three chemotypes have been reported in literature for U. lapponica: 1) usnic, salazinic acids with different medullary substances (protocetraric, barbatic, caperatic acids, zeorin) in Europe, North America (Halonen et al., 1998), and Russian Far East (Ohmura et al., 2017); 2) usnic and psoromic acids in Europe (Halonen et al., 1999); 3) usnic acid in Europe and North America (Randlane et al., 2009).

Three chemotypes were found - usnic, salazinic, barbatic acids; usnic acid; usnic, salazinic acids.

Specimens examined: Aliger Lake surroundings, $44^{\circ} 01^{\prime} 45.8^{\prime \prime N}$, $145^{\circ} 43^{\prime} 12.7^{\prime \prime E}, 87 \mathrm{~m}$ a. s. 1., mixed coniferous-deciduous forest, bark of Betula ermanii, 20 VI 2014, Ezhkin, SAK 318; vicinity of Tretiakova village, $43^{\circ} 58^{\prime} 28.4^{\prime \prime N}, 145^{\circ} 39^{\prime} 49.3^{\prime \prime E}, 163 \mathrm{~m}$ a. s. 1., mixed coniferous-deciduous forest, bark of Ulmus laciniata, 22 VI 2014, Ezhkin, SAK 321; ibidem, 4353'23.5"N, 145³6'37.7"E, 36 m a. s. 1., old-growth mixed coniferous-broadleaved forest, bark of U. laciniata, 23 VI 2014, Ezhkin, SAK 1240; Mendeleev Volcano surroundings, 4359'30.4"N, 14545'59.7"E, $183 \mathrm{~m}$ a. s. 1., spruce-fir forest, bark of Abies sachalinensis, 24 VI 2014, Ezhkin, SAK 335.

U. longissima Ach. Ten chemotypes have been reported for U. longissima: 1) usnic and barbatic acids in Japan (Ohmura, 2001), Europe (Randlane et al., 2009), North America (Halonen et al., 1998); 2) usnic and diffractaic acids in Japan (Ohmura, 2001), Europe (Randlane et al., 2009), North America (Halonen et al., 1998); 3) usnic and evernic acids in Japan (Ohmura, 2001), Europe (Randlane et al., 2009), North America (Halonen et al., 1998), and Russian Far East (Ohmura et al., 2017); 4) usnic and salazinic acids in Japan (Asahina, 1956); 5) usnic and fumarpotocetraric acids in Japan (Asahina, 1956); 6) usnic, barbatic, 4-O-demethylbarbatic, and squamatic ( \pm ) acids in Taiwan (Ohmura, 2012); 7) usnic, diffractaic, and barbatic acids in Taiwan (Ohmura, 2012); 8) usnic, evernic, and lecanoric acids in Taiwan (Ohmura, 2012); 9) usnic, barbatic (trace), diffractaic, baeomycesic, and squamatic acids in Russian Far East (Ohmura et al., 2017); 10) usnic acid in Europe and North America (Halonen, 1998).

One chemical race was recognized in the study area - usnic acid.

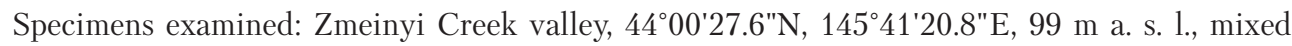
coniferous-deciduous forest, bark of Hydrangea paniculata Siebold, 31 VII 2013, Ezhkin, SAK 357; ibidem, $44^{\circ} 00^{\prime} 28.1^{\prime \prime N}, 145^{\circ} 41^{\prime} 39.0^{\prime \prime} \mathrm{E}, 158 \mathrm{~m}$ a. s. 1., mixed coniferous-deciduous forest, bark of Abies sachalinensis, 31 VII 2013, Ezhkin, SAK 340; Belkina River valley, 4354'10.9"N, 145³5'51.1"E, $56 \mathrm{~m}$ a. s. 1., mixed coniferous-deciduous forest, bark of Ulmus laciniata, 23 VI 2014, Ezhkin, SAK 348; ibidem, $43^{\circ} 53^{\prime} 51.5^{\prime \prime} \mathrm{N}, 145^{\circ} 36^{\prime} 22.5^{\prime \prime} \mathrm{E}, 70 \mathrm{~m}$ a. s. 1., mixed coniferous-deciduous forest, bark of Abies sachalinensis, 23 VI 2014, Ezhkin, SAK 339.

U. pangiana Stirt. Three chemotypes have been reported for U.pangiana: 1) usnic, salazinic, norstictic $( \pm)$, protocetraric $( \pm)$, constictic $( \pm)$, and squamatic $( \pm)$ acids in Taiwan, Japan (Ohmura, 2001, 2012), and Russian Far East (Ohmura et al., 2017); 2) usnic, salazinic, barbatic, 4-O-demethylbarbatic, norstictic $( \pm)$, and protocetraric 
$( \pm$ ) acids, atranorin ( \pm ) in Taiwan and Japan (Ohmura, 2001, 2012); 3) usnic acid in Russian Far East (Ohmura et al., 2017).

Two chemical races were found - usnic, salazinic acids; usnic, salazinic, barbatic acids.

Specimens examined: Belkina River valley, $43^{\circ} 53^{\prime 2} 21.9^{\prime \prime N}, 145^{\circ} 36^{\prime} 54.7^{\prime \prime E}, 30 \mathrm{~m}$ a. s. 1., mixed coniferous-deciduous forest, bark of Betula ermanii, 22 VI 2014, Ezhkin, SAK 373, 372, 370, 368; ibidem, $43^{\circ} 54^{\prime} 12.1$ "N, $145^{\circ} 36^{\prime} 04.1^{\prime \prime E}, 77 \mathrm{~m}$ a. s. l., mixed coniferous-deciduous forest, bark of B. ermanii, 23 VI 2014, Ezhkin, SAK 345, 342; ibidem, 435''13.1"N, 145³6'15.4"E, 57 m a. s. l., mixed forest, bark of Salix caprea L., 23 VI 2014, Ezhkin, SAK 338; ibidem, 4353'23.5"N, 145³6'37.7"E, $36 \mathrm{~m}$ a. s. l., mixed coniferous-deciduous forest, bark of Betula ermanii, 23 VI 2014, Ezhkin, SAK 374 ; vicinity of Tretiakova village, $43^{\circ} 58^{\prime} 34.1 \mathrm{~N}^{\prime \prime}, 145^{\circ} 39^{\prime} 45.4^{\prime \prime E}, 191 \mathrm{~m}$ a. s. 1., mixed coniferous-deciduous forest, bark of Taxus cuspidata Siebold et Zucc. ex Endl., 22 VI 2014, Ezhkin, SAK 319; ibidem, $43^{\circ} 58^{\prime} 28.4^{\prime \prime N}, 145^{\circ} 39^{\prime} 49.3^{\prime} \mathrm{E}, 163 \mathrm{~m}$ a. s. l., mixed coniferous-deciduous forest, bark of $U l$ mus laciniata, 22 VI 2014, Ezhkin, SAK 320; ibidem, bark of Phellodendron sakhalinense (F. Schmidt) Sarg., 22 VI 2015, Ezhkin, SAK 1246; ibidem, old-growth mixed coniferous-broadleaved forest, bark of Abies sakhalinensis, 22 VI 2015, Ezhkin, SAK 1247; Mendeleev Volcano surroundings, Mechnikov Mt., $43^{\circ} 58^{\prime} 15.9^{\prime \prime N}, 145^{\circ} 43^{\prime} 34.1$ "E, $547 \mathrm{~m}$ a. s. 1., fir forest, bark of A. sachalinensis, 13 VIII 2013, Ezhkin, SAK 333, 334; ibidem, 4358'33.7"N, 14543'19.8"E, 468 m a. s. l., coniferous forest, bark of Sorbus commixta, 6 VIII 2013, Ezhkin, SAK 1237; ibidem, 4359'23.3"N, 14547'5.1"E, 94 m a. s. l., spruce-fir forest, bark of Abies sachalinensis, 24 VI 2014, Ezhkin, SAK 336, 1248; Mendeleev Volcano, $44^{\circ} 00^{\prime} 04.8^{\prime \prime N}, 145^{\circ} 42 ' 26.8^{\prime \prime E}, 134 \mathrm{~m}$ a. s. l., mixed coniferous-deciduous forest, bark of Picea jezoensis, 26 VIII 2013, Ezhkin, SAK 326; ibidem, 4359'21.8"N, 14546'16.7"E, 197 m a. s. 1., spruce-fir forest, bark of Sorbus commixta, 11 VIII 2015, Ezhkin, SAK 330; ibidem, 4359'31.9"N, 145²3'15.6"E, 317 m a. s. l., coniferous forest, bark of Abies sakhalinensis, 28 VII 2013, Ezhkin, SAK 1252; Dubovoye village surroundings, $43^{\circ} 46^{\prime} 28.7^{\prime \prime} \mathrm{N}, 145^{\circ} 31^{\prime} 00.9^{\prime} \mathrm{E}, 58 \mathrm{~m}$ a. s. l., oak forest, bark of Quersus crispula,

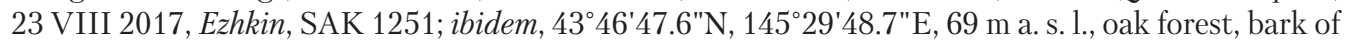
Q. crispula, 23 VIII 2017, Ezhkin, SAK 1239, 1238; Golovnino Volcano surroundings, 4352'51.6"N, 14536'20.3"E, 89 m a. s. l., mixed forest, bark of Sorbus commixta, 22 VIII 2017, Ezhkin, SAK 1242; ibidem, $43^{\circ} 52^{\prime} 20.9^{\prime \prime} \mathrm{N}, 145^{\circ} 36^{\prime} 00.9^{\prime} \mathrm{E}, 89 \mathrm{~m}$ a. s. l., mixed forest, bark of Quersus crispula, 23 VIII 2017, Ezhkin, SAK 1241.

Usnea rubicunda Stirt. Four chemotypes have been reported in literature for $U$. rubicunda: 1) usnic and stictic acids as a main substances, and norstictic and psoromic acids as accessories in Europe (James et al., 2009; Randlane et al., 2009) and Japan (Asahina, 1956); 2) usnic and salazinic acids as a main substances and norstictic acid as an accessory in Europe (James et al., 2009; Randlane et al., 2009); 3) usnic, norstictic, stictic, menegazziaic, constictic, and squamatic $( \pm)$ acids and atranorin $( \pm)$ in Taiwan (Ohmura, 2012); 4) usnic, norstictic, stictic, menegazziaic, constictic, psoromic, and 2-O-demethylpsoromic ( \pm ) acids in Taiwan (Ohmura, 2012) and Russian Far East (Ohmura et al., 2017).

Two chemical races were found - usnic, salazinic, norstictic acids; usnic acid. Chemotype without medullary substances (usnic acid in cortex) was not previously known for this species.

Specimens examined: Belkina River valley, $43^{\circ} 53^{\prime} 23.5^{\prime \prime N}$, $145^{\circ} 36^{\prime} 37.7^{\prime \prime E}, 36 \mathrm{~m}$ a. s. 1., mixed coniferous-deciduous forest, bark of Abies sachalinensis, 23 VI 2014, Ezhkin, SAK 360, 361, 358, 362, 359; ibidem, $43^{\circ} 53^{\prime} 24.8^{\prime \prime} \mathrm{N}, 145^{\circ} 36^{\prime} 28.3^{\prime \prime E}, 66 \mathrm{~m}$ a. s. l., mixed coniferous-deciduous forest, bark of 
A. sachalinensis, 23 VI 2014, Ezhkin, SAK 364, 365; Golovnino Volcano surroundings, 4352'51.6"N, $145^{\circ} 36^{\prime} 20.3^{\prime \prime E}, 89 \mathrm{~m}$ a. s. l., mixed forest, bark of A. sakhalinensis, 22 VIII 2017, Ezhkin, SAK 1249, 1243.

U. subfloridana Stirt. Four chemotypes have been reported for U. subfloridana: 1) usnic and squamatic acids in Europe, North America (Randlane et al., 2009), Russian Far East (Ohmura et al., 2017), Taiwan, and Japan (Ohmura, 2001); 2) usnic and thamnolic acids in Europe, North America (Randlane et al., 2009), Taiwan (Ohmura, 2012), and Japan (Ohmura, 2001); 3) usnic, squamatic, thamnolic, and alectorialic ( \pm ) acids in Europe, North America (Randlane et al., 2009), Taiwan, and Japan (Ohmura, 2001); 4) usnic, norstictic acids in Taiwan and Japan (Ohmura, 2001).

One chemotype was found - usnic, salazinic, barbatic acids. Chemotype with salazinic and barbatic acids was not previously known for this species. Among known Usnea species, $U$. wasmuthii Räsänen has similar chemotype, but differs by its morphological features, e. g. by more excavate soralia with few or without isidiomorphs and basal part with tiny, lenticular, longitudinally oriented cracks. All studied specimens lacked mentioned features and had typical morphology for U. subfloridana.

Specimens examined: Belkina River valley, $43^{\circ} 53^{\prime} 51.5^{\prime \prime} \mathrm{N}, 145^{\circ} 36^{\prime} 22.5^{\prime \prime} \mathrm{E}, 70 \mathrm{~m}$ a. s. 1., mixed coniferous-deciduous forest, bark of Sorbus commixta, 23 VI 2014, Ezhkin, SAK 346; Dubovoye village surroundings, $43^{\circ} 46^{\prime} 28.7^{\prime \prime} \mathrm{N}, 145^{\circ} 31^{\prime} 00.9^{\prime \prime E}, 58 \mathrm{~m}$ a. s. l., oak forest, bark of Quersus crispula, 23 VIII 2017, Ezhkin, SAK 1250; ibidem, 43 ${ }^{\circ} 47^{\prime} 47.0^{\prime \prime N}, 145^{\circ} 30^{\prime} 15.3 " \mathrm{E}, 107 \mathrm{~m}$ a. s. 1., oak forest, bark of Q. cris-

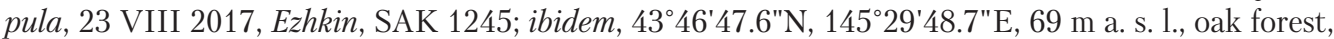
bark of Q. crispula, 23 VIII 2017, Ezhkin, SAK 1238.

\section{Conclusion}

In total, six secondary medullary substances were detected in Usnea species growing on Kunashir Island: barbatic, diffractaic, norstictic, protocetraric, salazinic, and thamnolic acids. Four new chemotypes were discovered: 1) U. glabrata - usnic, protocetraric, salazinic, thamnolic acids; 2) U. glabrata - usnic, protocetraric, salazinic acids; 3) U. rubicunda - usnic acid; 4) U. subfloridana - usnic, salazinic, barbatic acids. In our opinion, new chemotypes can be described from different countries as most of Usnea species have a relatively complex chemistry.

\section{Acknowledgments}

The work was partially supported by the Russian Foundation of Basic Researches (No. 18-04-00098 A, 19-54-50010) and institutional research project "Flora and systematics of lichens and mosses in Russia and phytogeographically important regions" (AAAA-A19-119020690077-4). We are grateful to Yoshihito Ohmura (National Museum of Nature and Science, Japan) for identification of U. pangiana sample with using DNA methods. We thank Alexander Kordyukov (Institute of Marine Geology and Geophysics FEB RAS, Yuzhno-Sakhalinsk, Russia) for preparing the map. The authors also thank Andrei Tsurykau (Francisk Skorina Gomel State University, Gomel, Belarus; Institute of Natural Sciences, Samara National Research University, Samara, Russia) for valuable comments on the manuscript. 


\section{References}

Articus K. 2004. Neuropogon and the phylogeny of Usnea s. 1. (Parmeliaceae, Lichenized Ascomycetes). Taxon 53(4): 925-934. https://doi.org/10.2307/4135560

Asahina Y. 1956. Lichens of Japan. Vol. 3. Genus Usnea. Tokyo: 129 p.

Bredkina I. I., Dobrysh A. A., Makarova I. I., Titov A. N. 1992. To the lichen flora of Kunashir Island (Kuril Islands). Novosti sistematiki nizshikh rastenii 28: 90-94. (In Russ.).

Brodo I. M., Sharnoff D. S., Sharnoff S. 2001. Lichens of North America. New Haven: 795 p.

Clerc P. 1987. On the morphology of soralia in the genus Usnea. Bibliotheca lichenologica 25: 99-107.

Clerc P. 2007. Usnea. Lichen flora of the Greater Sonoran Desert Region. Vol. 3. Tempe: 302-335.

Clerc P. 2011. Usnea. Nordic lichen flora. Vol. 4. Uppsala: 107-127.

Culberson C. F., Ammann K. K. 1979. Standardmethode zur Dünnschichtchromatographie von Flechtensubstanzen. Herzogia 5: 1-24. (In Germ.).

Divakar P. K., Crespo A., Kraichak E., Leavitt S. D., Singh G., Schmitt I., Lumbsch H. T. 2017. Using a temporal phylogenetic method to harmonize family- and genus-level classification in the largest clade of lichen-forming fungi. Fungal Diversity 84(1): 101-117.

https://doi.org/10.1007/s13225-017-0379-z

Dombrovskaya A. V. 1996. Rod Stereocaulon na territorii byvshego SSSR [Genus Stereocaulon in the former USSR]. St. Petersburg: 270 p. (In Russ.).

Ezhkin A. K., Kordyukov A. V. 2016. Features of changes in the parameters of the epiphytic lichen cover in the vicinity of the Mendeleyev volcano (Kunashir Island, South Kuriles). Bulletin of the Botanical Garden and Institute FEB RAS 15: 26-28. (In Russ.).

Golubkova N. S. 1996. Usnea. Opredelitel lishaynikov Rossii. Vyp. 3 [Handbook of the lichens of Russia. Iss. 6]. St. Petersburg: 62-107. (In Russ.).

Halonen P., Clerc P., Goward T., Brodo I., Wulff K. 1998. Synopsis of the genus Usnea (lichenized Ascomycetes) in British Columbia, Canada. The Bryologist 101(1): 36-60. https://doi.org/10.2307/3244073

Halonen P., Myllus L., Ahti T., Petrova V. O. 1999. The lichen genus Usnea in East Fennoscandia. III. The shrubby species. Annales Botanici Fennici 36: 235-256.

Insarov G. E., Pchelkin A. V. 1988. Kolichestvennye kharakteristiki sostoyaniya epifitnoi likhenoflory Kuril'skogo zapovednika [Quantitative characteristics of epiphytic lichen flora of Kuril'skiy Reserve]. Moscow: 174 p. (In Russ.).

James P. W., Clerc P., Purvis O. W. 2009. Usnea Dill. ex Adans. The Lichens of Great Britain and Ireland. London: 918-929.

Jayalal U., Joshi S., Oh S.-O., Jin Koh Y., Crişan F., Hur J.-S. 2013. Lichen mycota in South Korea: The Genus Usnea. Mycobiology 41(3): 126-130. https://doi.org/10.5941/MYCO.2013.41.3.126

Joneson S., Kashiwadani H., Tchabanenko S., Gage S. 2004. Ramalina of the Kuril Islands. The Bryologist 107(1): 98-106. https://doi.org/10.1639/0007-2745(2004)107[98:ROTKI]2.0.CO;2

Kharpukhaeva T. M. 2011. Species of the genus Usnea (Parmeliaceae) in Republic of Buryatia. Novosti sistematiki nizshikh rastenii 45: 257-266 (In Russ. with Engl. abstract). https://doi.org/10.31111/nsnr/2011.45.257

Kranner I., Beckett R. P., Varma A. K. 2002. Protocols in lichenology. Berlin, Heidelberg: 580 p. https://doi.org/10.1007/978-3-642-56359-1

Makryi T. V., Taran T. V., Tchabanenko S. I. 2010. Collema complanatum (Collemataceae, Lichenes) - a new species of lichen flora of Russia. Botanicheskii Zhurnal 95 (7): 989-991. (In Russ. with Engl. abstract).

Myllys L. 1994. Usnea glabrata (lichenized Ascomycotina) in East Fennoscandia. Acta Botanica Fennica 150: 125-130. 
Ohmura Y. 2001. Taxonomic study of the genus Usnea (lichenized Ascomycetes) in Japan and Taiwan. The Journal of the Hattori Botanical Laboratory 90: 1-96. https://doi.org/10.18968/jhbl.90.0_1

Ohmura Y. 2002. Phylogenetic evaluation of infrageneric groups of the genus Usnea based on ITS regions in rDNA. The Journal of the Hattori Botanical Laboratory 92: 231-243. https://doi.org/10.18968/jhbl.92.0_231

Ohmura Y. 2012. A Synopsis of the lichen genus Usnea (Parmeliaceae, Ascomycota) in Taiwan. Memoirs of National Museum of Nature and Science, Tokyo 48: 91-137.

Ohmura Y., Skirina I., Skirin F. 2017. Contribution to the knowledge of the genus Usnea (Parmeliaceae, Ascomycota) in Southern Far East Russia. Bulletin of the National Museum of Nature and Science, Series B (Botany), Tokyo 43(1): 1-10.

Ohmura Y., Kashiwadani H. 2018. Checklist of lichens and allied fungi of Japan. National Museum of Nature and Science Monographs 49: 1-140.

Randlane T., Tõrra T., Saag A., Saag L. 2009. Key to European Usnea species. Bibliotheca lichenologica 100: 419-462.

Spisok lichenoflory Rossii [A checklist of the lichen flora of Russia]. 2010. St. Petersburg: 194 p. (In Russ. with Engl. introduction).

Stevens G. N. 1999. A revision of the lichen family Usneaceae in Australia. Bibliotheca lichenologica 72: $1-128$.

Takhtadzhyan A. L. 1978. Floristicheskie oblasti Zemli [The floristic regions of the World]. Leningrad: 248 p. (In Russ.).

Tchabanenko S. I. 1999. Lichens of Kuril Researve (the Kunashir Island). Issledovanie rastitel'nogo pokrova rossiiskogo Dal'nego Vostoka. Trudy botanicheskikh sadov DVO RAN. T. 1. [Study of the vegetation cover of the Russian Far East. Proceedings of the Botanical Gardens of the Far-East Branch of the Russian Academy of Sciences. Vol. 1.]. Vladivostok: 221-228. (In Russ.).

Titov A. N. 1991. Lichens of the order Caliciales from the Kunashir Island (the Kuril Islands). Botanicheskii zhurnal 76(4): 599-601. (In Russ.).

Wijayawardene N. N., Hyde K. D., Al-Ani L. K. T., Tedersoo L., Haelewaters D., Rajeshkumar K. C., Zhao R. L., Aptroot A., Leontyev D. V., Saxena R. K. et al. 2020. Outline of fungi and fungus-like taxa. Mycosphere 11(1): 1060-1456. https://doi.org/10.5943/mycosphere/11/1/8

\section{Литература}

Articus K. 2004. Neuropogon and the phylogeny of Usnea s. 1. (Parmeliaceae, Lichenized Ascomycetes). Taxon 53(4): 925-934. https://doi.org/10.2307/4135560

Asahina Y. 1956. Lichens of Japan. Vol. 3. Genus Usnea. Tokyo: 129 p.

[Bredkina et al.] Бредкина Л. И., Добрыш А. А., Макарова И. И., Титов А. Н. 1992. К флоре лишайников острова Кунашир (Курильские острова). Новости систематики низших растений 28: 90-94.

Brodo I. M., Sharnoff D. S., Sharnoff S. 2001. Lichens of North America. New Haven: 795 p.

Clerc P. 1987. On the morphology of soralia in the genus Usnea. Bibliotheca lichenologica 25: 99-107.

Clerc P. 2007. Usnea. Lichen flora of the Greater Sonoran Desert Region. Vol. 3. Tempe: 302-335.

Clerc P. 2011. Usnea. Nordic lichen flora. Vol. 4. Uppsala: 107-127.

Culberson C. F., Ammann K. K. 1979. Standardmethode zur Dünnschichtchromatographie von Flechtensubstanzen. Herzogia 5: 1-24.

Divakar P. K., Crespo A., Kraichak E., Leavitt S. D., Singh G., Schmitt I., Lumbsch H. T. 2017. Using a temporal phylogenetic method to harmonize family- and genus-level classification in the largest clade of lichen-forming fungi. Fungal Diversity 84(1): 101-117.

https://doi.org/10.1007/s13225-017-0379-z 
[Dombrovskaya] Домбровская А. В. 1996. Род Stereocaulon на территории бывщего СССР. СПб.: $270 \mathrm{c}$.

[Ezhkin, Kordyukov] Ежкин А. К., Кордюков А. В. 2016. Особенности изменения параметров эпифитного лишайникового покрова в окрестностях вулкана Менделеева (о-в Кунашир, Южные Курилы). Бюллетень Ботанического сада-института ДВО РАН 15: 23-25.

[Golubkova] Голубкова Н. С. 1996. Usnеа. Определитель лишайников России. Вып. 6. СПб.: 62-107.

Halonen P., Clerc P., Goward T., Brodo I., Wulff K. 1998. Synopsis of the Genus Usnea (Lichenized Ascomycetes) in British Columbia, Canada. The Bryologist 101(1): 36-60. https://doi.org/10.2307/3244073

Halonen P., Myllus L., Ahti T., Petrova V. O. 1999. The lichen genus Usnea in East Fennoscandia. III. The shrubby species. Annales Botanici Fennici 36: 235-256.

[Insarov, Pchelkin] Инсаров Г. Э., Пчелкин А. В. 1984. Количественные характеристики состояния эпифитной лихенофлоры Курильского заповедника. М.: 174 с.

James P. W., Clerc P., Purvis O. W. 2009. Usnea Dill. ex Adans. The Lichens of Great Britain and Ireland. London: 918-929.

Jayalal U., Joshi S., Oh S.-O., Jin Koh Y., Crişan F., Hur J.-S. 2013. Lichen mycota in South Korea: The genus Usnea. Mycobiology 41(3): 126-130. https://doi.org/10.5941/MYCO.2013.41.3.126

Joneson S., Kashiwadani H., Tchabanenko S., Gage S. 2004. Ramalina of the Kuril Islands. The Bryologist 107(1): 98-106. https://doi.org/10.1639/0007-2745(2004)107[98:ROTKI]2.0.CO;2

[Kharpukhaeva] Харпухаева T. M. 2011. Виды рода Usnea (Parmeliaceae) в Республике Бурятия. Новости систематики низших растений 45: 257-266. https://doi.org/10.31111/nsnr/2011.45.257

Kranner I., Beckett R. P., Varma A. K. 2002. Protocols in lichenology. Berlin, Heidelberg: 580 p. https://doi.org/10.1007/978-3-642-56359-1

[Makryi et al.] Макрый Т. В., Таран А. А., Чабаненко С. И. 2010. Collema complanatum (Collemataceae) новый вид для лихеофлоры России. Ботанический журнал 95(7): 989-991.

Myllys L. 1994. Usnea glabrata (lichenized Ascomycotina) in East Fennoscandia. Acta Botanica Fennica 150: 125-130.

Ohmura Y. 2001. Taxonomic study of the genus Usnea (lichenized Ascomycetes) in Japan and Taiwan. The Journal of the Hattori Botanical Laboratory 90: 1-96. https://doi.org/10.18968/jhbl.90.0_1

Ohmura Y. 2002. Phylogenetic evaluation of infrageneric groups of the genus Usnea based on ITS regions in rDNA. The Journal of the Hattori Botanical Laboratory 92: 231-243. https://doi.org/10.18968/jhbl.92.0_231

Ohmura Y. 2012. A synopsis of the lichen genus Usnea (Parmeliaceae, Ascomycota) in Taiwan. Memoirs of National Museum of Nature and Science, Tokyo 48: 91-137.

Ohmura Y., Skirina I., Skirin F. 2017. Contribution to the knowledge of the genus Usnea (Parmeliaceae, Ascomycota) in Southern Far East Russia. Bulletin of the National Museum of Nature and Science, Series B (Botany), Tokyo 43(1): 1-10.

Ohmura Y., Kashiwadani H. 2018. Checklist of lichens and allied fungi of Japan. National Museum of Nature and Science Monographs 49: 1-140.

Randlane T., Tõrra T., Saag A., Saag L. 2009. Key to European Usnea species. Bibliotheca lichenologica 100: 419-462.

[Spisok...] Список лихенофлоры России. 2010. СПб.: 194 c.

Stevens G. N. 1999. A revision of the lichen family Usneaceae in Australia. Bibliotheca lichenologica 72: $1-128$.

[Takhtadzhyan] Тахтаджян А. Л. 1978. Флористические области Земли. Л.: 248 с. 
[Tchabanenko] Чабаненко С. И. 1999. Лишайники Курильского заповедника (остров Кунашир). Исследование растительного покрова российского Дальнего Востока. Труды ботанических садов ДВО РАН. Т. 1. Владивосток: 221-228.

[Titov] Титов А. Н. 1991. Лишайники порядка Caliciales с острова Кунашир (Курильские острова). Ботанический журнал 76(4): 599-601.

Wijayawardene N. N., Hyde K. D., Al-Ani L. K. T., Tedersoo L., Haelewaters D., Rajeshkumar K. C., Zhao R. L., Aptroot A., Leontyev D. V., Saxena R. K. et al. 2020. Outline of fungi and fungus-like taxa. Mycosphere 11(1): 1060-1456. https://doi.org/10.5943/mycosphere/11/1/8 